\title{
Needs Analysis on the Competence of Secondary School Mathematics Teachers: Springboard for a Teacher Training Module
}

\author{
Rey Avila Mangarin ${ }^{1}$, Liezel V. Chan ${ }^{2}$ \\ ${ }^{I}$ Student, MAEd Teaching Mathematics, The University of Mindanao \\ ${ }^{2}$ Dean, College, UM Panabo College
}

\begin{abstract}
The purpose of this quantitative non-experimental descriptive-comparative research was to generate a Teacher Training Program for Mathematics Teachers based on an InputOutput (IO) Model addressing the needs competence of Mathematics teachers in a certain Division of DepEd Region XI. Online survey on the Needs Analysis utilizing google form was conducted considering complete enumeration and in the analysis of data mean, t-test, and ANOVA were used. The results showed of all seven dimensions, two are in high level competence which are planning instruction and managing instruction; while the other five are in very high level which are: improving personal competence, specifying objectives for instruction, diagnosing and evaluating learning, delivering instruction, and administering instructional facilities and equipment. Further, it was found out that there was no significant difference on the competence of Mathematics teachers when analyzed by length of service, position, educational attainment, and age. The Teacher Training Program proposed is a two-week self-management learning program utilizing the Planning and Managing Instruction Effectively: A Self-Regulated Module formulated by the researcher.
\end{abstract}

Keywords: Needs Analysis, Competence, Teacher Training Program, Inpu-Output Model, Department of Education

\section{BACKGROUND OF THE STUDY}

$\mathrm{M}$ athematics is always regarded as the most difficult subject to be learned and to be taught. The performance of students in mathematics is low compared to other subjects in the curricula. From the national level down to school level, various strategies were employed to address this issue and Mathematics teachers are always encouraged to design and implement new plans on how to improve the achievement of students in Mathematics (Aplaon, 2017).

Meanwhile, school leaders are challenged by the relatively limited supply and high turnover of qualified secondary school mathematics teachers. In response to this concept, policy makers and teacher educators have developed various pathways and incentives to recruit, train, place, and support highly qualified mathematics teachers to work in hard-to-staff schools. While Mathematics teachers in Western countries are facing with an expectation that they make significant change to their teaching, but research shows a little embedded success with this claim (Golding, 2017).
In 2015, regional economic integration in the Association of South East Asian Nations (ASEAN) Community took place where there was an inescapable increase of diverse students in ASEAN Community classrooms. This led to a movement towards educational readiness preparation in Thailand but the movement was not specific regarding classroom practices where Mathematics teachers have not yet been well prepared to deal with such diversity. It is then suggested that there is a pressing need to prepare Mathematics teachers for diverse classrooms which will address the issues related to diversity in mathematics classrooms and preparing mathematics teachers to teach diverse groups of students (Katwibun, 2013).

Additionally, the discrepancy between school and academic Mathematics as well as the resulting problems for secondary mathematics teachers' needs has been well known since then. Even up to now, the field of mathematics education has no clear answers to the question as to what kind of professionspecific content knowledge secondary mathematics teachers need and should be taught during the course of their teacher education. Research has shown that many professional development initiatives appear ineffective in supporting changes in teacher practices and student learning. There are methodologically rigorous studies that have demonstrated a positive link between teacher professional development, teaching practices, and student outcomes. It is very important to identify the features of the professional development to replicate them (Darling-Hammond, Hyler, \& Gardner, 2017).

A research conducted by Reuben, Sogillo, Guimba, and Alico (2016) entitled Assessment of Mathematics Teachers in a Public and a Private School: Implications to the Quality of Teaching Secondary Mathematics in Agusan del Norte, Philippines, found out that one group of students has poor achievement due to poor teaching quality manifested by teachers. The research suggests that teachers should continually improve their teaching methods, more preferably focusing on all the learning domains. The study cited above provides a recommendation for the mathematics teachers to acquire relevant trainings for their own holistic development.

Thus, the researcher came up with the idea of analyzing the needs of secondary school mathematics teachers to keep 
themselves abreast with the current demands in teaching and learning mathematics. This is essential as to relative actions to be undertaken to prepare teachers in meeting with these local challenges as well as confronting issues of globalization. In addition, after the analysis and identification of those needs, a program design shall be crafted to enhance proficiency in teaching and address the needs of the teachers. The program shall be recommended to be implemented in the Department of Education, Division of Panabo City, in partnership with The University of Mindanao.

\section{THEORETICAL FRAMEWORK}

The following theories, concepts, and propositions were selected as bases where this study was anchored to:

This study was primarily affixed to Hierarchy of Needs of Maslow (1943) as cited by Cherry (2019) which states that people have an inborn desire to be self-actualized, that is, to be all they can be. In order to achieve these ultimate goals, however, a number of more basic needs must be met such as the need for food, safety, love, and self-esteem.

The abovementioned theory was similarly applied in this research such that the basic professional needs and competence of Secondary Schools Mathematics teachers need to be addressed to actualize their professional roles.

The Parkinson's Law which originated from an essay by British Naval Historian Cyril Northcote Parkinson (19091993) as cited by Amorado (2011) is another basis of this study. The said principle states that work expands to fill the time available which is a powerful tool in understanding the never ending needs and wants of human beings. Thus, it is very important to meet the needs of the Mathematics teachers through a teacher training program in order to avoid the idea that people will be brought to their stupidity and inutility when work expands over time.

Additionally, Jusoh, Salleh, Embong, and Mamat (2019) cited Mestry and Grobler (2005) who proposed the "Iceberg" Model which states that knowledge and skills are more easily developed and identified than difficult to identify which can be used as another basis for this study.

In the abovementioned, the model was significant since the analysis of the needs revolves around the knowledge and skills of Mathematics teachers as manifested in the field.

Further, this study was anchored to Nain's (2013) Model on Hierarchy of Needs which is particularly applicable in an organizational perspective. This model advocates that instead of blindly applying Maslow's Theory of Motivation to all employees alike, there should a personalized approach to employee motivation since needs vary from person to person and from one employee to another employee.

Nain's Model was applicable since in this research, the needs will be analyzed according to the demographic profile and will be understood to the group they belong. In similar context, the above proposition serves as baseline since this study aims to identify the needs in order to generate a training program for secondary schools Mathematics teachers to address the needs.

The view cited by Aplaon (2017) from Educational Initiatives (2010) that presently, teacher quality and student achievement have tight relationship and that teachers should be mentored and provided with specific feedback on their areas of strength and weakness both in subject content and related aspects like how students learn which actually can help build teacher capacity and improve students' learning.

The abovementioned was applicable since the end output of this study shall be a teacher training program where mentoring from feedback insights based on the survey assessment will be dealt accordingly. When teaching training program successfully addresses the needs of teachers, their performance will be improved thus directly improving students' achievement.

Lastly, this study was anchored on the recommendation of Zakaria and Daud (2009) that a needs analysis research should be conducted for all pre-service and in-service mathematics teachers since the findings of such research would provide guidelines for pre-service and in-service training planners. It is further stressed that ongoing professional development programs are required by teachers in order to become more effective in teaching.

\section{CONCEPTUAL FRAMEWORK}

This study utilized the Input-Output Model as shown below. In here, the input will be the gathered data of needs from the secondary school Math teachers of the Division of Panabo City for the S.Y. 2019-2020.

The input was represented by the Needs Variable which conceptually refers to the discrepancy, a recognized problem, the requirement for more services, and the wants of Mathematics teachers with seven identified indicators of needs which are: Improving Personal Competence which refers to how teachers enhance the students' attitude, cognitive dimension, and historical background in Mathematics, Specifying Objectives for Instruction refers to the ability of teachers in the assessment of learning for both difficulties and achievement of students, Diagnosing and Evaluating Learning refers to the ability of teachers in selecting and developing materials and lessons, Planning Instruction refers to the teachers' use of varied strategies and techniques in teaching Mathematics, Delivering Instruction refers to the use of materials and physical space in teaching Mathematics, Managing Instruction refers to the ability of teachers in the use of materials and other sources for teaching, and Administering Instructional Facilities and Equipment refers to how teachers update knowledge in teaching Mathematics (Rakumako and Laugksch, 2010).

The output of this research was a recommended intervention scheme, particularly, a Teacher Training Program for Mathematics teachers, based on the data gathered and 
analyzed. Moderating variables, to wit: position, length of service, educational attainment, and age bracket, were used to

INPUT identify the needs of the math teachers in terms of profile.

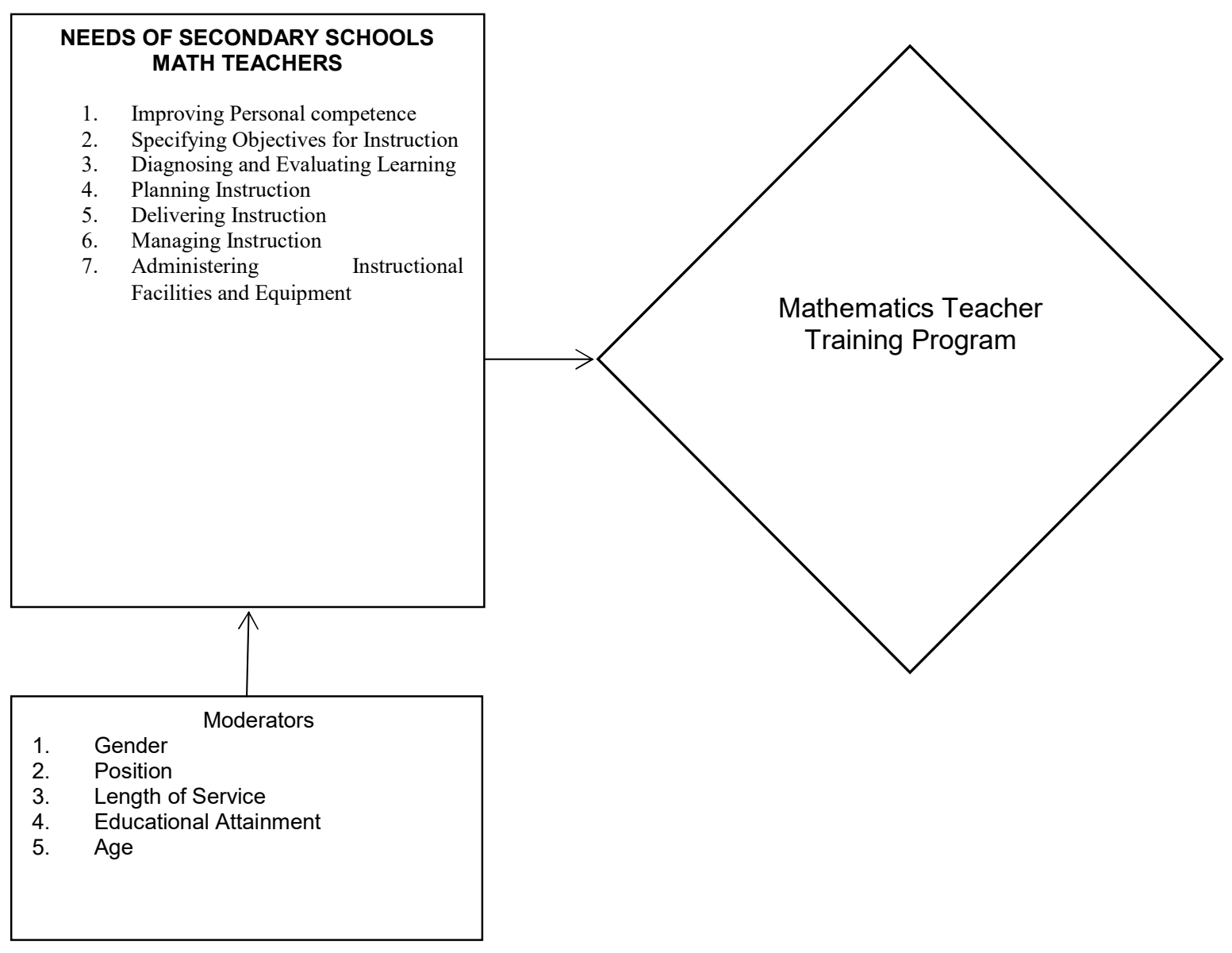

Figure 1: The Conceptual Paradigm Showing the Variables of the Study

\section{Research Objectives}

The main purpose of this study was to craft program to address the competence of secondary school teachers in Mathematics in the Division of Panabo City. Specifically, this aimed:

1. To determine the demographic profile of secondary school teachers in Mathematics in the Division of Panabo City in terms of:

1.1. length of service,

1.2. position,

1.3. educational attainment, and

1.4. age

2. To determine the competence of secondary school math teachers in terms of:

2.1. improving personal competence,

2.2. specifying objectives for instruction,

2.3. diagnosing and evaluating learning,

2.4. planning instruction,
2.5. delivering instruction,

2.6. managing instruction, and

2.7. Administering instructional facilities and equipment.

3. To determine the significant difference in the competence of secondary math teachers when analyzed by:

3.1. length of service,

3.2. position,

3.3. educational attainment, and

3.4. age

4. To design an intervention program to be proposed to address the needs of secondary school math teachers.

\section{Hypothesis}

The hypothesis that there was no significant difference in the needs level of secondary school math teachers in terms of length of service, position rank, educational attainment, and age was tested at 0.05 level of significance. 


\section{RESEARCH DESIGN}

This study utilized quantitative non-experimental descriptivecomparative survey research. Almeida, Gaerlan, and Manly suggested that survey research uses questionnaires to get a sense of behavior with intense precision and allows researcher to judge behavior and then present findings in an accurate way. Survey research can be conducted around one specific group or used to compare several groups.

Additionally, McCombs (2019) explains that this research design aims to accurately and systematically describe a population, situation or phenomenon. A descriptive research design can use a wide variety of quantitative and qualitative methods to investigate one or more variables. Descriptive research is an appropriate choice when the research aim is to identify characteristics, frequencies, trends, correlations, and categories. It is useful when not much is known yet about the topic or problem. It allows you to gather large volumes of data that can be analyzed for frequencies, averages and patterns.

Moreover, Atmowardoyo (2018) emphasized that descriptive research is defined as a research method used to describe the existing phenomena as accurately as possible. he phenomena observed in descriptive research are already available. What is necessary for a researcher to do is collecting the available data through the use of research instruments such as test, questionnaire, interview, or even observation. The main goal of descriptive research is to describe systematically the existing phenomena under the study.

This design is appropriate in this study because like the function of this design, this study described the demographics of the Mathematics teachers in the Division of Davao del Norte, gauge their perceptions on their needs as Mathematics teachers, evaluate their own to what they need and enhance more, and then compare the needs level based on the set grouping variables.

Meanwhile, the Input-Output (IO) Model is a functional graph that identifies the inputs, outputs, and required processing tasks required to transform inputs into outputs. The model is sometimes organized to include any sequence in the process as well. The inputs represent the flow of data and materials into the process from the outside. The processing step includes all tasks required to effect a transformation of the inputs. The outputs are the data and materials flowing out of the transformation process (Schembri, 2012). Additionally, Input-Output models are designed to analyze the various positive and negative impacts on a certain dimension of education (Yih, Hsu, \& Li, 2018).

Despite theoretical advances, input-output models have been empirically applied only to a limited extent. This is mainly due to the fact that the number of parameters to be estimated is much higher than the number of available data points (Fernandez-Vasquez, 2015).
Also, Kenton (2018) emphasized that input-output analysis ("I-O") is a form of macroeconomic analysis based on the interdependencies between economic sectors or industries. This method is commonly used for estimating the impacts of positive or negative economic shocks and analyzing the ripple effects throughout an economy. This type of economic analysis was originally developed by Wassily Leontief (19051999), who later won the Nobel Memorial Prize in Economic Sciences for his work in this area. I-O has been employed in Marxist economic analysis of coordinated economies that rely on a central planner.

The use of Input-Output model justifies the purpose of this study since the inputs considered are the needs level identified as basis to crafting of output which was the Teacher Training Program which will be used to address the needs of the secondary school Mathematics teachers.

\section{Research Locale}

This study was conducted in Panabo City. The City of Panabo is a third class city in the province of Davao del Norte, Philippines. It is a coastal component city in the province of Davao del Norte with a land area of 251.23 square kilometers which constitutes $7.33 \%$ of Davao del Norte's total area. Panabo has 40 barangays. The city center of Panabo is situated at approximately $7^{\circ} 18^{\prime}$ North, $125^{\circ} 41^{\prime}$ East, in the island of Mindanao. Elevation at these coordinates is estimated at 6.5 meters or 21.3 feet above mean sea level.

In terms of population as determined by the 2015 Census, there was 184,599 which represents $18.16 \%$ of the total population of Davao del Norte province or $3.77 \%$ of the overall population of Region XI. The age group with the highest population is 5 to 9 , with 19,696 individuals. Conversely, the age group with the lowest population is 80 and over, with 1,011 individuals. The population of Panabo grew from 42,509 in 1960 to 184,599 in 2015, an increase of 142,090 people. The latest census figures in 2015 denote a positive growth rate of $1.09 \%$, or an increase of 10,235 people, from the previous population of 174,364 in 2010The population density is computed at 735 inhabitants per square kilometer.

Specifically, the study was conducted at the Division of Panabo City, Department of Education. Particularly, the said Division has 12 secondary schools which are actually the work residences of the respondents of the study which are: A.O. Floirendo, Cagangohan, Kasilak, Little Panay, Mabunao, Malativas, Panabo, Panabo City, Quizon, San Vicente, Southern Davao, and Sindaton National High Schools. These schools are proportionally distributed among different parts of Panabo City to cater the needs of the students in every barangay. 


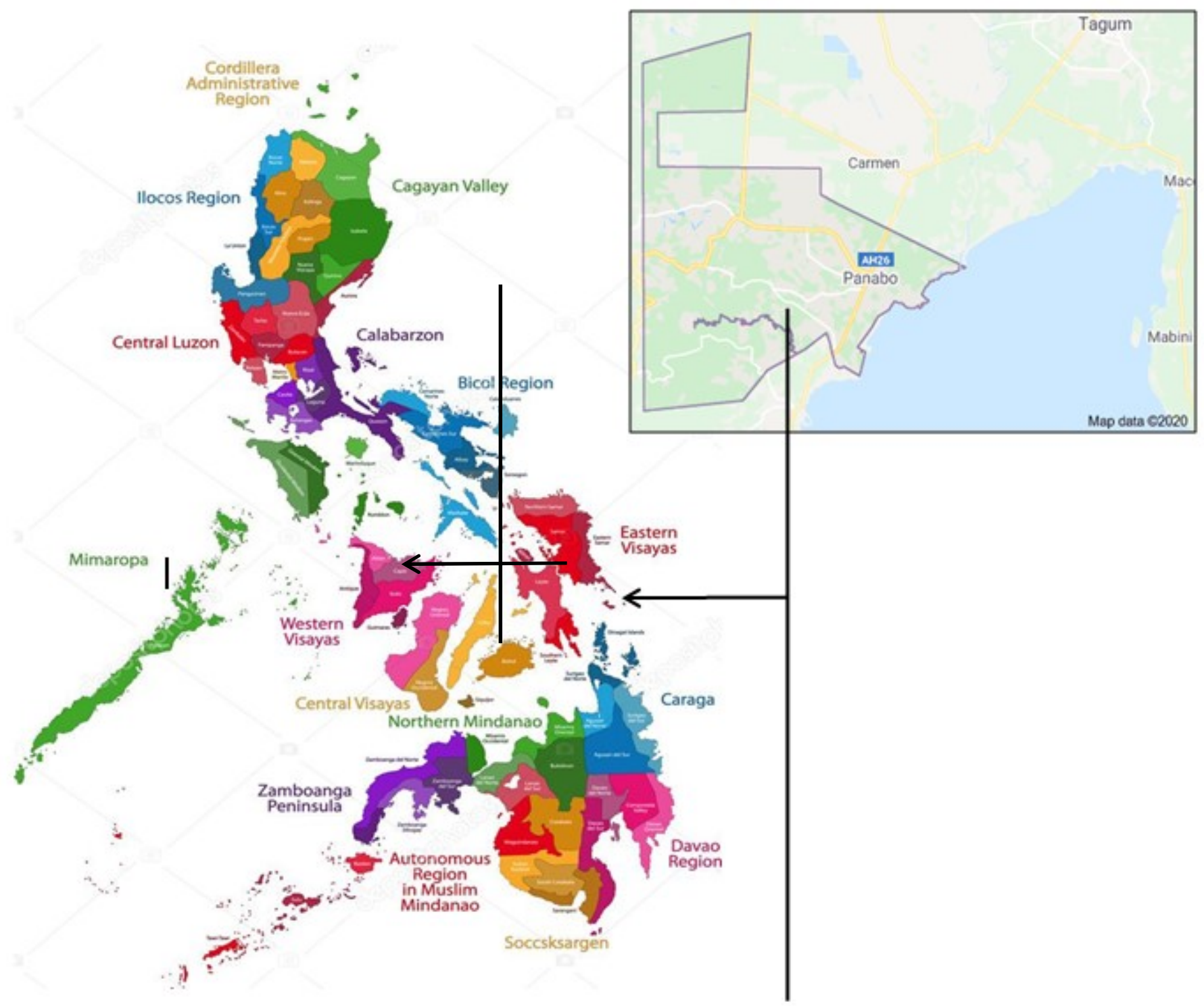

Figure 2: Map of Panabo City

\section{Research Respondents}

The respondents of the study were the secondary school teachers in Mathematics of the Division of Panabo City for the S.Y. 2020-2021. They are public school teachers handling Mathematics subjects whether they are regular-permanent or still Local School Board paid as long as they are teaching in public secondary schools. Other than described above like those public school teachers who are not teaching Mathematics, they were included as respondents. However, since this study observes ethical consideration, despite that the population is set, those who withdrew in the middle of the data collection or those who did not participate in the survey were not compelled since this is of voluntary basis. The consideration of the whole population or the complete enumeration of secondary school teachers in Mathematics in the Division of Panabo City is not that big enough is the major reason.
The population considered in this study as Alferez and Duro (2018) explained that population is a complete and entire collection of element to be studied. In addition, De Belen and Feliciano (2015) refers the entire number of people under study when considered called complete enumeration. Moreover, Arnab (2017) added that the sampling error is absent in a complete enumeration or census procedure but in collecting information from a unit in complete enumeration, the information regarding the value of the characteristic under study is not free from error. That non-sampling error arises at any stage of conducting a survey such as planning, data collection, processing the data, and tabulation as well report writing.

Additionally, this also considered purposive sampling technique since acoording to Ang-ug, Casocot, Garcia, and 
Tado (2014), this technique is based on the selection of respondents determined based on the belief that they could be the sufficient group to purposively address the phenomenon and objective of the research. The criteria have been laid down as abovementioned.

\section{Statistical Treatment}

The response gathered from the questionnaire were tallied and tabulated in a master data sheet. Statistics needed to answer the sub-problems were as follows:

Frequency/Percentage: This was used to answer the objective number 1 regarding the demographic profile of the respondents in terms of position, educational attainment, and length of service, and age.

Weighted Mean: This was used to measure the competence as basis for needs level among the Secondary School Math teachers.

Analysis of Variance (ANOVA): This was used in testing the hypothesis on the difference of the needs level among the secondary math teachers in terms of position, educational attainment, and length of service, and age.

\section{Research Instrument}

A researcher-made questionnaire was the instrument used to determine the needs level of secondary schools math teachers. The questionnaire contains 38 items under the seven identified indicators which are Improving Personal Competence with three items, Specifying Objectives for Instruction with two items, Diagnosing and Evaluating Learning with three items, Planning Instruction with 14 items, Delivering Instruction with four items, Managing Instruction with three items, and Administering Instructional Facilities and Equipment with nine items.

The following scale shall was used to describe the needs level of secondary schools mathematics teachers in the Division of Panabo City:

\begin{tabular}{|c|c|c|}
\hline $\begin{array}{c}\text { Range } \\
\text { of } \\
\text { Means }\end{array}$ & $\begin{array}{c}\text { Descriptive } \\
\text { Level }\end{array}$ & Interpretation \\
\hline $\begin{array}{c}4.20- \\
5.00\end{array}$ & Very High & $\begin{array}{c}\text { This means that competence of } \\
\text { Mathematics teachers is excellent and } \\
\text { that there is a very low needs level. }\end{array}$ \\
\hline $\begin{array}{c}\text { This means that competence of } \\
4.40-\end{array}$ & High & $\begin{array}{c}\text { Mathematics teachers is very good } \\
\text { and that there is a low needs level. }\end{array}$ \\
\hline $2.60-$ & Moderate & $\begin{array}{c}\text { This means that competence of } \\
\text { Mathematics teachers is good and that } \\
\text { there is a moderate needs level. }\end{array}$ \\
\hline 3.39 & Low & $\begin{array}{c}\text { This means that competence of } \\
\text { Mathematics teachers is poor and that } \\
\text { there is a high needs level. }\end{array}$ \\
\hline $1.80-$ & Very Low & $\begin{array}{c}\text { This means that competence of } \\
\text { Mathematics teachers is very poor and } \\
\text { that there is a very high needs level. }\end{array}$ \\
\hline $1.0-$
\end{tabular}

The survey questionnaire was validated by the panel of experts with a validity index of 3.74 . The first draft of the research instrument was submitted to the research adviser for comments, suggestions and recommendations to improve its presentation with the corrections to be included and integrated. The final copies were submitted to panel of experts for refinement. The final revision was made by incorporating the corrections, comments and suggestions given by the expert validators before the gathering of data. Pilot testing was done among 30 Mathematics teachers in a certain public school in Davao del Norte and the Cronbach alpha was computed and found to be 0.937 with a description of very high reliability.

\section{RESULTS}

\section{The Demographic Profile of Mathematics Teachers}

Shown in Table 1 is the demographic profile of Mathematics teachers in terms of length of service, position, educational attainment, and age.

Table 1: Demographic Profile of Mathematics

\begin{tabular}{|c|c|c|c|}
\hline Variable & Category & Frequency & Percentage \\
\hline \multirow{6}{*}{$\begin{array}{l}\text { Length of } \\
\text { Service }\end{array}$} & 0 to 3 years & 29 & $27.60 \%$ \\
\hline & Above 3 to 8 Years & 39 & $37.10 \%$ \\
\hline & Above 8 to 13 Years & 19 & $18.10 \%$ \\
\hline & Above 13 to 20 Years & 7 & $6.70 \%$ \\
\hline & Above 20 Years & 11 & $10.50 \%$ \\
\hline & Total & 105 & $100 \%$ \\
\hline \multirow{7}{*}{$\begin{array}{l}\text { Position } \\
\text { Rank }\end{array}$} & Teacher I & 64 & $61.00 \%$ \\
\hline & Teacher II & 19 & $18.10 \%$ \\
\hline & Teacher III & 19 & $18.10 \%$ \\
\hline & Master I & 2 & $1.90 \%$ \\
\hline & Master II & 1 & $1.00 \%$ \\
\hline & Master III & 0 & $0.00 \%$ \\
\hline & Total & 105 & $100 \%$ \\
\hline \multirow{6}{*}{$\begin{array}{l}\text { Educational } \\
\text { Attainment }\end{array}$} & Bachelor's Degree & 36 & $34.30 \%$ \\
\hline & $\begin{array}{l}\text { Master's Degree } \\
\text { (Undergraduate) }\end{array}$ & 46 & $43.80 \%$ \\
\hline & $\begin{array}{l}\text { Master's Degree (Full- } \\
\text { fledged) }\end{array}$ & 18 & $17.10 \%$ \\
\hline & $\begin{array}{c}\text { Doctorate } \\
\text { (Undergraduate) }\end{array}$ & 3 & $2.90 \%$ \\
\hline & Doctorate (Full-fledged) & 2 & $1.90 \%$ \\
\hline & Total & 105 & $100 \%$ \\
\hline \multirow{6}{*}{ Age } & $21-30$ Years Old & 40 & $38.10 \%$ \\
\hline & $31-40$ Years Old & 43 & $41.00 \%$ \\
\hline & $41-50$ Years Old & 14 & $13.30 \%$ \\
\hline & $51-60$ Years Old & 8 & $7.60 \%$ \\
\hline & Above 60 Years Old & 0 & $0.00 \%$ \\
\hline & Total & 105 & $100 \%$ \\
\hline
\end{tabular}


In terms of years of service, majority of mathematics teachers are serving for more than three to eight years which comprises the $27.60 \%(\mathrm{n}=39)$. This is followed by mathematics teachers serving for at most three years which is $27.60 \%$ $(\mathrm{n}=29)$. Third in rank are the mathematics teachers who were in service for eight to 13 years which is $18.10 \%(n=19)$. While there is only $10.50 \%(\mathrm{n}=11)$ of mathematics teachers who are in service for more than 20 years, the least number are the teachers who are serving for 13 to 20 years which is $6.70 \%$ $(n=7)$ of the population.

Considering the position rank, majority of mathematics teachers' item is Teacher I which comprised $61.00 \%(n=64)$ of the population. Then this is followed by both Teacher II and Teacher III position which shared exactly the same percentage of $18.10 \%(\mathrm{n}=19)$. There is only one Master Teacher II which is $1.00 \%$ of the population while there are only two Master Teacher I in Mathematics which is only $1.90 \%$ of the population.

Looking at the educational attainment, majority of teachers have not completed their Master's Degree which is $43.80 \%$ (n $=46$ ). Next to it are mathematics teachers who didn't take professional or graduate studies which is $34.30 \%(\mathrm{n}=36)$. While those who successfully completed their Master's Degree are only 18 teachers which is $17.10 \%$ of the entire population. There are three mathematics teachers who have not completed their Doctorate Degree which is $2.90 \%$ while there are only two mathematics teachers who completed their Doctorate Degree which is $1.90 \%$ of the population.

In terms of age category, teacher respondents aging $31-40$ years old are majority in number which comprises $41.00 \%$ (n $=43$ ). Next are the teacher respondents aging $21-30$ years old which comprises $38.10 \%(\mathrm{n}=40)$. There is only $13.30 \%$ $(\mathrm{n}=14)$ of teacher respondents aging $41-50$ years old while $7.60 \%(\mathrm{n}=8)$ of the teachers belong to $51-60$ years old. There is none of the teacher respondents who are above the retirement age which is 60 years old.

\section{The Competence of Mathematics Teachers}

The table below shows that mathematics teachers have very high level in competence in terms of the indicators shown.

Of all seven indicators, two are in high level competence which are planning instruction $(x=4.06 ; S . D .=0.54)$, and managing instruction $(x=4.15 ; S . D .=0.62)$; while the other five are in very high level which are: improve personal competence $(x=4.36 ;$ S.D. $=0.53)$, specifying objectives for instruction $(x=4.27 ;$ S.D. $=0.53)$, diagnosing and evaluating learning $(x=4.21$; S.D. $=0.56)$, delivering instruction $(x=4.32$; $S . D .=0.51)$, and administering instructional facilities and equipment ( $x=4.21$; S.D. $=0.57)$.

Table 2: The Competence Level of Mathematics Teachers

\begin{tabular}{|c|c|c|c|}
\hline Factor & Mean & S.D. & Description \\
\hline $\begin{array}{c}\text { Improving Personal } \\
\text { Competence }\end{array}$ & 4.36 & 0.53 & Very High \\
\hline
\end{tabular}

\begin{tabular}{|c|c|c|c|}
\hline $\begin{array}{c}\text { Specifying Objectives for } \\
\text { Instruction }\end{array}$ & 4.27 & 0.53 & Very High \\
\hline $\begin{array}{c}\text { Diagnosing and } \\
\text { Evaluating Learning }\end{array}$ & 4.21 & 0.56 & Very High \\
\hline Planning Instruction & 4.06 & 0.54 & High \\
\hline Delivering Instruction & 4.32 & 0.51 & Very High \\
\hline Managing Instruction & 4.15 & 0.62 & High \\
\hline $\begin{array}{c}\text { Administering } \\
\text { Instructional Facilities and } \\
\text { Equipment }\end{array}$ & 4.21 & 0.57 & Very High \\
\hline Over-all & 4.18 & 0.49 & High \\
\hline
\end{tabular}

Planning instruction and managing instruction are two dimensions which are in high level. This indicates that Mathematics teachers have very satisfactory ability to use varied strategies and techniques in teaching Mathematics and other sources for teaching. While dimensions that are in a very high level are improving personal competence, specifying objectives for instruction, diagnosing and evaluating learning, delivering instruction, and administering instructional facilities and equipment. The higher the competence a teacher has, the lower the needs to be addressed. This result imply that teachers have excellent ability to enhance the students' attitude, cognitive dimension, and historical background in Mathematics, assessment of learning for both difficulties and achievement of students, selecting and developing materials and lessons, use of materials and physical space in teaching Mathematics, and update knowledge in teaching Mathematics.

The Significant Difference on Competence of Mathematics Teachers when Analyzed by Length of Service

As depicted in Table 3, it was found out that there was no significant difference $(f$-value $=1.736 ; p$-value $>0.05)$ on competence of mathematics teachers who served at most three years $(x=4.36$; S.D. $=0.40)$ which is very high level, above three to eight years $(x=4.14 ;$ S.D. $=0.54)$ which is in high level, above eight to 13 years $(x=4.12 ; S . D .=0.40)$ which is high, above 13 to 20 years $(x=3.98 ; S . D .=0.62)$ which is in high level, and above 20 years in service $(x=4.03 ;$ S.D. $=0.49)$ which is also in high level.

\begin{tabular}{|c|c|c|c|c|c|}
\hline Variable & Mean & S.D. & $\begin{array}{c}\text { Descriptive } \\
\text { Equivalent }\end{array}$ & f-value & $\begin{array}{c}\text { p- } \\
\text { value }\end{array}$ \\
\hline 0 to 3 years & 4.36 & 0.40 & Very High & & \\
\cline { 1 - 4 } $\begin{array}{c}\text { Above } 3 \text { to } \\
8 \text { Years }\end{array}$ & 4.14 & 0.54 & High & & \\
\cline { 1 - 4 } $\begin{array}{c}\text { Above } 8 \text { to } \\
\text { 13 Years }\end{array}$ & 4.12 & 0.40 & High & \multirow{2}{*}{1.736} & \multirow{2}{*}{0.148} \\
\cline { 1 - 4 } $\begin{array}{c}\text { Above } 13 \text { to } \\
\text { 20 Years }\end{array}$ & 3.98 & 0.62 & High & & \\
\cline { 1 - 4 } $\begin{array}{c}\text { Above } 20 \\
\text { Years }\end{array}$ & 4.03 & 0.49 & High & & \\
\hline
\end{tabular}

Table 3: The Significant Difference on Competence when Analyzed by Length of Service. 


\section{The Significant Difference on Competence of Mathematics Teachers when Analyzed by Position Rank}

As shown in Table 4, it was found out that there was no significant difference $(f$-value $=1.997 ; p$-value $>0.05)$ on competence between mathematics teachers who are Teacher I $(x=4.24 ;$ S.D. $=0.45)$ which is very high, Teacher II $(x=3.98$; S.D. $=0.56)$ which is high, Teacher III $(x=4.09 ;$ S.D. $=0.48)$ which is in high level, Master Teacher I $(x=4.28 ;$ S.D. $=0.02)$ which is very high, and Master Teacher II $(x=3.98$; $S . D .=0.62)$ which is also in very high level.

Table 4: The Significant Difference on Competence when Analyzed by Position or Rank

\begin{tabular}{|c|c|c|c|c|c|}
\hline Variable & Mean & S.D. & $\begin{array}{l}\text { Descriptive } \\
\text { Equivalent }\end{array}$ & f-value & $\begin{array}{c}\mathrm{p}- \\
\text { value }\end{array}$ \\
\hline Teacher I & 4.24 & 0.45 & Very High & \multirow{5}{*}{1.997} & \multirow{5}{*}{0.101} \\
\hline Teacher II & 3.98 & 0.56 & High & & \\
\hline Teacher III & 4.09 & 0.48 & High & & \\
\hline Master I & 4.28 & 0.02 & Very High & & \\
\hline Master II & 5.00 & N/A & Very High & & \\
\hline
\end{tabular}

The Significant Difference on Competence of Mathematics Teachers when Analyzed by Educational Attainment

As shown in Table 5, it was found out that there was no significant difference $(f$-value $=0.812 ; p$-value $>0.05)$ on competence between mathematics teachers who are only Bachelor's Degree holders $(x=4.21 ; S . D .=0.48)$ which is very high, Undergraduate Master's Degree holders $(x=4.10$; $S . D .=0.48)$ which is high, Master's Degree holders $(x=4.26$; $S . D .=0.51)$ which is in a very high level, Undergraduate Doctorate Degree holders $(x=4.17 ;$ S.D. $=0.61)$ which is high, and Doctorate Degree Holder $(x=4.59 ;$;.D. $=0.58)$ which is also in very high level.

Table 5: The Significant Difference on SPS when Analyzed by Educational Attainment

\begin{tabular}{|c|c|c|c|c|c|}
\hline Variable & Mean & S.D. & $\begin{array}{c}\text { Descriptive } \\
\text { Equivalent }\end{array}$ & $\begin{array}{c}\mathrm{f}- \\
\text { value }\end{array}$ & $\begin{array}{c}\mathrm{p}- \\
\text { value }\end{array}$ \\
\cline { 1 - 4 } Bachelor's Degree & 4.21 & 0.48 & Very High & & \\
\cline { 1 - 4 } Master's Degree & 4.10 & 0.48 & High & 0.812 & 0.520 \\
\hline
\end{tabular}

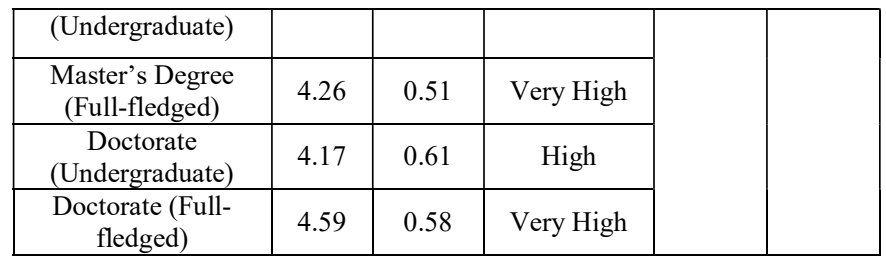

The Significant Difference on Competence of Mathematics Teachers when Analyzed by Age Bracket

As shown in Table 6, it was found out that there was no significant difference $(f$-value $=1.826 ; p$-value $>0.05)$ on competence between mathematics teachers who are $21-30$ years old $(x=4.30 ;$;.D. $=0.47)$ which is very high, $31-40$ years old $(x=4.14 ;$ S.D. $=0.50)$ which is high, $41-50$ years old $(x=4.00 ;$ S.D. $=0.39)$ which is in a high level, and $51-60$ years old $(x=4.04 ;$ S.D. $=0.55)$ which is also high.

Table 6: The Significant Difference on Competence when Analyzed by Age Bracket.

\begin{tabular}{|c|c|c|c|c|c|}
\hline Variable & Mean & S.D. & $\begin{array}{c}\text { Descriptive } \\
\text { Equivalent }\end{array}$ & f-value & p-value \\
\hline $\begin{array}{c}21-30 \\
\text { Years Old }\end{array}$ & 4.30 & 0.47 & Very High & & \\
\cline { 1 - 4 } $\begin{array}{c}31-40 \\
\text { Years Old }\end{array}$ & 4.14 & 0.50 & High & & \\
\hline $\begin{array}{c}41-50 \\
\text { Years Old }\end{array}$ & 4.00 & 0.39 & High & \multirow{2}{*}{1.826} & \multirow{2}{*}{0.147} \\
\cline { 1 - 4 } $\begin{array}{c}51-60 \\
\text { Years Old }\end{array}$ & 4.04 & 0.55 & High & & \\
\cline { 1 - 3 } & & & \\
\hline
\end{tabular}

The Teacher Training Program for Mathematics Teachers

Based on the results above, Matrix 1 presents the summary of the important points that Mathematics teacher' needs to be addressed through the teacher training program crafted by the researcher. As shown in the matrix, important points are highlighted which need to be included in the training programs which are based from the results generated. Activities are suggested to address the important points with corresponding responsible agency to do the implementation of the schemes in partnership with some agencies or persons on the implementation

Matrix 1: Strategic Activities in the Mathematics Teacher Training Program for Enhancement of Competence

\begin{tabular}{|c|c|c|c|c|}
\hline Important Points & Basis & Activity & $\begin{array}{c}\text { Responsible } \\
\text { Agency }\end{array}$ & Partner Agency/Person \\
\hline $\begin{array}{c}\text { Significance of Graduate and } \\
\text { Professional Studies }\end{array}$ & Profiling & Profession Dynamics Orientation & Division Office & $\begin{array}{c}\text { UM Professional Schools } \\
\text { Panabo Offsite }\end{array}$ \\
\hline Understanding Paths for Promotion & Profiling & Orientation on Promotion Guidelines & Division Office & $\begin{array}{c}\text { Department of Budget and } \\
\text { Management, Civil Service } \\
\text { Commission }\end{array}$ \\
\hline $\begin{array}{c}\text { Ideal Retirement Age in Scientific } \\
\text { and Health Context (Preparation for } \\
\text { Financial Stability) }\end{array}$ & Profiling & $\begin{array}{c}\text { Information-driven Seminar on Health } \\
\text { and Retirement Age/Financial } \\
\text { Wellness Program for Public Teachers }\end{array}$ & Division Office & $\begin{array}{c}\text { Department of Health/Financial } \\
\text { Advisor Firms }\end{array}$ \\
\hline $\begin{array}{c}\text { Self-instructional Module on } \\
\text { Enhancing Planning and Managing } \\
\text { Instruction in Mathematics }\end{array}$ & $\begin{array}{c}\text { Competence } \\
\text { Analysis Result }\end{array}$ & $\begin{array}{c}\text { Independent Learning for Two Least } \\
\text { Dimensions on Competence of } \\
\text { Mathematics Teachers }\end{array}$ & Division Office & $\begin{array}{c}\text { Researcher and UM } \\
\text { professional Schools }\end{array}$ \\
\hline
\end{tabular}




\section{CONCLUSION}

The following are conclusions gleaned from the results of this study:

In terms of years of service, majority of mathematics teachers are serving for more than three to eight year. This is followed by mathematics teachers serving for at most three years. Third in rank are the mathematics teachers who were in service for eight to 13 years. Next are mathematics teachers who are in service for more than 20 years, the least number are the teachers who are serving for 13 to 20 years.

Considering the position rank, majority of mathematics teachers' item is Teacher I. Then this is followed by both Teacher II and Teacher III position which shared exactly the same percentage. There is only one Master Teacher II while there are only two Master Teacher I in Mathematics.

Looking at the educational attainment, majority of teachers have not completed their Master's Degree. Next to it are mathematics teachers who didn't take professional or graduate studies. Next are those who successfully completed their Master's Degree. There are three mathematics teachers who have not completed their Doctorate Degree while there are only two mathematics teachers who completed their Doctorate Degree.

In terms of age category, teacher respondents aging $31-40$ years old are majority in number. Next are the teacher respondents aging $21-30$ years old. Next are teacher respondents aging $41-50$ years old and then teachers belong to $51-60$ years old. There is none of the teacher respondents who are above the retirement age which is 60 years old.

Of all seven indicators, two are in high level competence which are planning instruction and managing instruction; while the other five are in very high level which are: improve personal competence, specifying objectives for instruction, diagnosing and evaluating learning, delivering instruction, and administering instructional facilities and equipment.

It was found out that there was no significant difference on competence of mathematics teachers when analyzed by years in service. It was also found out that there was no significant difference on competence between mathematics teachers when analyzed by rank or position. It was also found out that there was no significant difference on competence between mathematics teachers when analyzed by educational attainment. Also, it was found out that there was no significant difference on competence of mathematics teachers when analyzed by age bracket.

Four suggested intervention programs as reflected below are deemed important to address the needs of the teachers in Mathematics. The first will be the Profession Dynamics Orientation which will provide significant insights on the importance of graduate and professional studies in the teaching profession. The suggestion of this intervention is due to the fact that majority of teachers are just contented in the bachelor's degree completion and there are very few who engaged to professional and graduate studies. The second one is Orientation on Promotion Guidelines since majority of teachers are not yet promoted. The provision of insights to teachers on the guidelines will help them seek strategies in meeting the standards in order to be promoted. The third one is Information-driven Seminar on Health and Retirement Age/Financial Wellness Program for Public Teachers to give them insights on preparation of their retirement with respect to health and financial stability. The last one and the highlight of this study is the self-instructional module intended for teachers in service for them to improve themselves and provide quality service to the students.

\section{RECOMMENDATION}

\section{With the above knowledge generated, the following are recommended:}

The authorities in the Department of Education and the school leaders are recommended to keep track the profiles of teachers to check the demographic profile needs. Also, teachers in Mathematics are recommended to check the professional aspects of themselves in order to take actions to what dimensions will be improved. Mathematics teachers are recommended to engage to professional studies and seek strategic ways on how to attain promotions in the teaching job.

Mathematics teachers are also recommended to improve their abilities in planning and managing instructions while they are recommended to maintain their competence in improving personal competence, specifying objectives for instruction, diagnosing and evaluating learning, delivering instruction, and administering instructional facilities and equipment.

Further research on the significant difference on the competence when analyzed by the different grouping variables is recommended. The crafted intervention programs are recommended to address the needs of secondary school Mathematics teachers.

This study is recommended to be replicated in other contexts and other dimensions on the competence and needs for confirmation and further generation of knowledge.

\section{REFERENCES}

[1] Alferez, M.S. \& Duro, M.A. (2018). Statistics and Probability. Philippines: MSA Publishing Company.

[2] Almeida, A.B., Gaerlan, A.A., \& Manly, N.E. (2016). Research Fundamentals: From concepts to outputs. Philippines: Adriana Publishing co., Inc.

[3] Ang-ug, E.F., Casocot, N.T., Garcia, R.F., \& Tado, P.P. (2014). College Statistics. Davao City: Blue Patriarch Publishing House.

[4] Arnab, R. (2017). Nonsampling Errors. Retrieved from https://www.sciencedirect.com/topics/mathematics/completeenumeration.

[5] Atmowardoyo, H. (2018). Research methods in TEFL studies: Descriptive research, case study, error analysis, and $R$ \& D. Journal of Language Teaching and Research, 9(1), 197-204. doi:http://dx.doi.org/10.17507/jltr.0901.25 
[6] Amorado, R. V. (20110. Kakistocracy: Rule of the unprincipled, unethical, and unqualified. Davao City: Research and Publication Office, Ateneo de Davao University.

[7] Aplaon, Z. (2017). Needs assessment of senior high school mathematics teachers in teaching statistics and probability. Retrieved

from researchgate.net/publication/334226177_NEEDS_ASSESSMENT OF SENIOR HIGH SCHOOL MATHEMATICS TEACHER $\bar{S}$ _IN_TEACHING_STATISTICS_AND_PROBABILITY on October 2019.

[8] Cherry, K. (2019). The 5 Levels of Maslow's Hierarchy of Needs. Retrieved from https://www.verywellmind.com/what-is-maslowshierarchy-of-needs-4136760.

[9] Darling-Hammond, L., Hyler, M.A., \& Gardner, M. (2017). Effective Teacher Professional Development. Retrieved from https://learningpolicyinstitute.org/product/effective-teacherprofessional-development-brief.

[10] De Belen, R.T. \& Feliciano, J.P. (2015). Basic statistics for research. Philippines: Wiseman's Books Trading, Inc.

[11] Fernandez-Vazquez, E. (2015). EMPIRICAL ESTIMATION OF NON-LINEAR INPUT-OUTPUT MODELS: AN ENTROPY ECONOMETRICS APPROACH. Economic Systems Research, 27(4), 508. Retrieved from https://search.proquest.com/docview/1761128142? accountid=312 59

[12] Golding, J. (2017). Mathematics teachers' capacity for change. Retrieved from https://www.tandfonline.com/doi/full/10.1080/03054985.2017.13 31846 .

[13] Jusoh, A., Salleh, M., Embong, R., \& Mamat, M. (2018). The Influence of Mathematical Teacher Competency on Creative Teaching Practice. International Journal of Academic Research in Progressive Education and Development, 7(4), 397-409. DOI: 10.6007/IJARPED/v7-i4/5333
[14] Katwibun, D. (2013). The need for preparing mathematics teachers for diverse classrooms in Thailand. Retrieved from https://pdf.sciencedirectassets.com/277811/1-s2.0S1877042813X00278/1-s2.0-S187704281303379X/main.pdf?XAmz-Security-Token=IQoJb3.

[15] Kenton, W. (2018). Input-Output Analysis. Retrieved from https://www.investopedia.com/terms/i/input-output-analysis.asp.

[16] McCombs, S. (2019). Descriptive research. Retrieved from https://www.scribbr.com/methodology/descriptive-research/.

[17] Nain, B. (2013). Nain's porous hierarchy of needs: An alternative to maslow's hierarchy of needs. Indian Journal of Positive Psychology, 4(3), 464-467. Retrieved from https://search.proquest.com/docview/1613959955?accountid=312 59

[18] Rakumako, A. \& Laughksch, R. (2010). Demographic profile and perceived INSET needs of secondary Mathematics teachers in Limpopo province. Retrieved https://www.semanticscholar.org/paper/Demographic-profile-andperceived-INSET-needs-of-in-RakumakoLaugksch/8b498c5b5b2d63a430423efed08325859155f0f4.

[19] Reuben, R., Sogillo, O., Guimba, W., \& Alico, J. (2016). Assessment of Mathematics Teachers in a Public and a Private School: Implications to the Quality of Teaching Secondary Mathematics. Retrieved from https://www.researchgate.net/publication/321010255 Assessment _of_Mathematics_Teachers_in_a_Public_and_a_Private_School_ Implications_to_the_Quality_of_Teaching_Secondary_Mathemati cs.

[20] Schembri, J. (2012). Input Output Model. Retrieved from https://www.sixsigmadaily.com/input-output-model/.

[21] Zakaria, E. \& Daud, M. Y. (2009). Assesing mathematics teachers' professional development needs. Retrieved from https://www.researchgate.net/publication/278848270_Assesing_m athematics_teachers'_professional_development_needs. 